\title{
Properties of soy protein isolate antimicrobial films and its application in preservation of meat
}

\author{
Yuanyuan Liu, Huajiang Zhang, Lina Xu, Yujie Chi, Yongqing Wu, Wenhui Cao, Tong Li \\ Food College, Northeast Agricultural University, Harbin, P.R. China
}

\section{A B S T R A C T}

\begin{abstract}
The soy protein isolate (SPI) antimicrobial films were made with Nisin (N), sodium lactate (NaL), EDTA (E) and their optical combination (C). The $C$ film showed a significant $(p<0.05)$ antimicrobial effect on three food pathogens, E. coli, Salmonella and Bacillus cereus, which inhibitory zone is $32 \mathrm{~mm}, 33.33 \mathrm{~mm}$ and $32.33 \mathrm{~mm}$, respectively. The addition of $\mathrm{N}$ and $\mathrm{NaL}$ to SPI film reduced its mechanical properties, that is, the tensile strength (TS) was reduced from $10.8716 \mathrm{MPa}$ to $8.1405 \mathrm{MPa}$ (N1) and $3.2715 \mathrm{MPa}$ (NaL3) and the elongation at break (E) was increased from $3.03 \%$ to $4.73 \%(N 3, N 4)$ and $11.21 \%$ (NaL4). While the addition of EDTA and combination increased TS from 10.8716MPa to $17.0600 \mathrm{MPa}$ (E4) and reduced $\mathrm{E}$ from $3.03 \%$ to $2.36 \%$ (E1). The water vapor permeability (WVP), oxygen permeability $(\mathrm{OP})$ and total color difference $(\Delta \mathrm{E})$ of films had changed with the addition of antimicrobial agents. The FTIR analysis showed no specific interaction between active groups of Nisin with functional group of control film. However, the intensity of peaks in the spectrum of NaL and EDTA increased, indicating interactions between NaL, EDTA and SPI. The appliction experments showed that the SPI antimicrobial film (C) did have a bacteriostatic preservation effect on the meat antibacterial preservation and extend the shelf life to 3-6 days compared with SPI film and ordinary wraps. The SPI antimicrobial film broadens the application of SPI film.
\end{abstract}

Keywords: Antimicrobial SPI film; Nisin; Sodium lactate; EDTA; Food pathogenic bacteria

\section{INTRODUCTION}

Food safety is a global priority and also one of the main objective of the current food legislation(Quintavalla et al., 2002). Particularly, bacterial contamination of readyto-eat products is of concern to human health (Pranoto et al., 2005). What can we do in the face of this tricky problem? There are three methods to reduce or prevent the growth of the bacteria in food product currently: (1) incorporation into the foodstuff; (2) dipping or pulverization; (3) incorporation into a film. There are already many studies about antimicrobial packaging films. The antimicrobial and physical properties of chitosan with Nisin were demonstrated by Wang et al. (2015), Li et al. (2006) and Pranoto et al. (2005). Wang et al. (2015) reported that the chitosan-based films incorporating sodium lactate could effectively inhibit the growth of E.coli. Dutta et al. (2009) demonstrated the potential of chitosan in the study of antimicrobial films. Theinsathid et al. (2011) reported that the biobased film incorporating sodium lactate were effective on the inhibitory of Listeria monocytogenes. Resa et al. (2016) and Pattanayaiying et al. (2015) all demonstrated that the starch antimicrobial edible films had potential in the application of food packaging for the preservation of food, such as ready-to-eat muscle foods and refrigerated argentinian port salut cheese. However, the majority of current researches on antimicrobial packaging films are about chitosan and starch based films, and the researches about SPI antimicrobial films are rarely seen.

SPI has been widely used in hydrogel, adhesives, plastics, films, coatings, and emulsifiers (Tian et al., 2010; Tian et al., 2008; Kumar et al., 2002; Gennadios et al., 1993) and has wide application in producing an edible antimicrobial film to employ the antimicrobial agents on the surface of the food products (Park et al., 2002; Eswaranandam et al., 2004; Gallagher et al., 2004; Silva et al., 2007). The antimicrobial and mechanical properties of the SPI films with various natural antimicrobials have been identified (Park et al., 2002; Ko et al., 2001). Zhao et al. (2013) reported that the SPI films can prevent the growth of bacteria and its useful life was prolonged with

\footnotetext{
*Corresponding author:

Huajiang Zhang, Food College, Northeast Agricultural University, Harbin, P.R. China. Mobile: 86 15704609331. E-mail: hjthzhang@163.com
}

Received: 10 May 2017; Revised: 25 September 2017; Accepted: 27 September 2017; Published Online: 09 October 2017 
the help of antimicrobial agents- $\mathrm{AgNO}_{3}$. Kim (2016) explored the inhibitory effect of SPI films incorporating cinnamaldehyde on the growth of microbals. Ko et al. (2001) and Eswaranandam et al. (2004) have demonstrated the antimicrobial and physical properties of SPI films with various natural antimicrobials.

Bacteriocins, particularly Nisin $(\mathrm{N})$, contain the natural antimicrobial substances that can be incorporated into the edible films to control the food-borne pathogens (Were et al., 1999; Yildirim et al., 1997; Dawson et al., 2003; Gennadios et al., 1996). Nisin is a food-grade bacterium (Quintavalla et al., 2002), which can be incorporated into the edible films to control various Gram-positive microbial growth including foodborne pathogens (Were et al., 1999; Yildirim et al., 1997; Dawson et al., 2003; Gennadios et al., 1996; Jin and Zhang, 2008). Nisin binds to the precursor of peptidoglycan and lipid II to inhibit the cell wall biosynthesis. It then forms the pores within the cell membrane that leads to the release of essential ions and, ultimately, it causes the cell death (Hsu et al., 2004). Nisin has been appoved by the Food and Drug Administration (FDA) used as a food preservative. Sodium lactate is the sodium salt of the low molecular weight organic acids. It can control the growth of microbial (Sallam, 2007) andwas used to extend the shelf life of many products (Long and Phillips, 2003; Juneja, 2006), which is non-toxic and commonly available (Schelegueda et al., 2012). EDTA is believed to release a huge Gramnegative lipo-polysaccharides from the outer membrane and expose the hydrophobic phospholipids which are able to increase the susceptibility to hydrophobic and cell wall degrading agents (Helander et al., 1997; Walsh et al., 2003). It improves the activity of nisin against Gram-negative bacteria, including E. Coli O157: H7 and S. Typhimurium (Stevens et al., 1991).

The development of the packaging material-related antimicrobial agents is an active area of research as a complementary method to inhibit the growth of food pathogens. The objectives of this research are: (1) to produce antimicrobial protein films for food coating and packaging from soy protein isolate; and (2) to determine their antimicobial properties, mechanical properties, barrier properties and color difference and to evaluate the potential of SPI films incorporated antimicrobial agents (nisin, sodium lactate, EDTA) for use as a antimicrobial coating/ film material. And the application experiments verified the feasibility of antimicrobial SPI-based films in food fresh packaging. In conclusion, the properties and application of incorporation of three antimicrobial in SPI films were discussed in the present study.

\section{MATERIALS AND METHODS}

\section{Materials}

Pathogenic bacteria Escherichia coli (CMCC 44103), Salmonella (CMCCB 50041) and Bacillus cereus (CICC 21261) were obtained from BNCC (Bena Culture Collection) Biological Technology Co., Ltd, China. Microbial media and nutrient agar (Hopebio Biological Technology Co., Ltd, Qingdao, China), soy protein isolate (SPI) (GS5100) (GUSHEN Biological Technology Co., Ltd, Shandong), glycerol, nisin, sodium lactate and EDTA (Sinopharm Chemical Reagent Co.,Ltd). All materials used are analytical reagent.

\section{Film formation}

SPI films were prepared using a casting method modified slightly from Wan et al. (2005). SPI solution (50g/L) and $0.4 \mathrm{~g} / \mathrm{g}$ glycerol (based on SPI content) was added into the solution (Wang et al., 2016). It was stirred with a magnetic stirrer (78HW-1) for $30 \mathrm{~min}$. Antimicrobials were then allowed to added to the solution before heating it in a water bath for $30 \mathrm{~min}$ at $60^{\circ} \mathrm{C}$. The $\mathrm{pH}$ was adjusted to 7 by pH meter (SIN-PH-100). Before being heated, control; Nisin: $\mathrm{N}_{1}$ (5000 IU/g SPI), $\mathrm{N}_{2}(10000 \mathrm{IU} / \mathrm{g}$ SPI), $\mathrm{N}_{3}(15000 \mathrm{IU} / g \mathrm{SPI}), \mathrm{N}_{4}(20000 \mathrm{IU} / \mathrm{g} \mathrm{SPI})$; Sodium Lactate: $\mathrm{NaL}_{1}(0.5 \mathrm{~g} / \mathrm{g} \mathrm{SPI}), \mathrm{NaL}_{2}(1.0 \mathrm{~g} / \mathrm{g}$ SPI), $\mathrm{NaL}_{3}(1.5 \mathrm{~g} / \mathrm{g} \mathrm{SPI}), \mathrm{NaL}_{4}(2.0 \mathrm{~g} / \mathrm{g}$ SPI); EDTA: $\mathrm{E}_{1}(0.04 \mathrm{~g} / \mathrm{g} \mathrm{SPI}), \mathrm{E}_{2}(0.08 \mathrm{~g} / \mathrm{g} \mathrm{SPI}), \mathrm{E}_{3}(0.12 \mathrm{~g} / \mathrm{g} \mathrm{SPI})$, $\mathrm{E}_{4}(0.16 \mathrm{~g} / \mathrm{g} \mathrm{SPI})$ and $\mathrm{E}_{5}(0.20 \mathrm{~g} / \mathrm{g} \mathrm{SPI})$ and their combination [N $(5000 \mathrm{IU} / \mathrm{g}$ SPI $)+\mathrm{NaL}(1.0 \mathrm{~g} / \mathrm{g} \mathrm{SPI})+\mathrm{E}$ $(0.08 \mathrm{~g} / \mathrm{g}$ SPI $)]$ were added into the film-forming solutions. All concentrations used in this study were selected based on our preliminary tests for formation of SPI films (Sivarooban et al., 2008). Then the solution was cooled to room temperature and then poured into the Plexiglas plates $(230 \mathrm{~mm} \times 230 \mathrm{~mm} \times 30 \mathrm{~mm})$ before dried in a vacuum drying oven for $12 \mathrm{~h}$ at $50^{\circ} \mathrm{C}$. The dried films were peeled off and conditioned again at $43 \% \mathrm{RH}$ and $25^{\circ} \mathrm{C}$ for $24 \mathrm{~h}$ prior to testing.

\section{Film characterization \\ Antimicrobial analysis}

The antimicrobial activity of SPI-based films was determined by agar diffusion method. In detail, the edible films were cut into a disc form of $20 \mathrm{~mm}$ diameter by a compasses knife. On the Mueller Hinton agar plates (Merck, Darmstadt, Germany) are the film cuts. They had been seeded in advance with $0.1 \mathrm{ml}$ of inoculum, with the indicator microorganisms included in $10^{5}-10^{6} \mathrm{CFU} / \mathrm{ml}$. Afterwards, they underwent incubatation at $37^{\circ} \mathrm{C}$ for $24 \mathrm{~h}$. The diameter or inhibitory zone surrounding film discs as well as contact area of films with agar surface were then measured. 


\section{Physical features of edible SPI film Thickness}

The average thickness ( $\mathrm{mm}$ ) of the edible film was measured by a hand micrometer at a few points (Aice, China). Based on the standard of the ASTM (American Society for Testing and Materials).

Tensile Strength (TS) and Elongation at break (E) The TS and E of the films was measured by TA Plus texture analyzer (SMS TA, UK). The prepared films were cut into $1.5 \mathrm{~cm} \times 10 \mathrm{~cm}$ strips. The films were held parallel with an initial grip separation of $5 \mathrm{~cm}$ and then pulled apart at a head speed of $25 \mathrm{~mm} / \mathrm{min}$. TS was calculated by dividing the maximum force at break (read from machine or computer contacted with the machine) by cross-sectional area of film.

$\mathrm{TS}=\frac{\mathrm{F} \times 10^{-6}}{\mathrm{~S}}$

Where $\mathrm{F}=$ maximum force at break $(\mathrm{N}) ; \mathrm{S}=$ cross-sectional area of film $\left(\mathrm{m}^{2}\right)$.

Percent E was calculated based on the length extended and original length of the films.

$\mathrm{E}=\frac{\Delta \mathrm{G}}{\mathrm{G}} \times 100 \%$

Where $\Delta \mathrm{G}=$ the length extended of the films $(\mathrm{cm}) ; \mathrm{G}=$ original length of the films $(\mathrm{cm})$.

\section{Water Vapor Permeability (WVP)}

The water vapor permeability (WVP) was determined gravimetrically using a modified ASTM procedure as used by Gontard et al. (1994). WVP was as below:

$\mathrm{W} V \mathrm{P}=\frac{\mathrm{w} \times \mathrm{x}}{\mathrm{A} \times \mathrm{t} \times \Delta \mathrm{P}}$

where $\mathrm{w}=$ weight gain of the beaker $(\mathrm{g})$; = film thickness (m); $\mathrm{A}=$ area of the exposed film $\left(\mathrm{m}^{2}\right) ; \mathrm{t}=$ time of weight gain (s); and $\Delta \mathrm{P}=$ water vapor partial pressure difference $\mathrm{Pa}$ across the two sides of the film calculated on the basis of relative humidity.

\section{Oxygen permeability (OP)}

The oxygen permeability (OP) was determined according to Wang et al. (2015).

Oxygen transmission rate (OTR, according to ASTMD1434) of film was determined at $23^{\circ} \mathrm{C}$ and $0 \% \mathrm{RH}$ on a Labthink gas permeameter (Jinan Labthink Electrical and Mechanical Technology Co., Ltd, Shandong, China). Oxygen permeability (OP) was calculated from OTR $\left(\mathrm{cm}^{3} \mathrm{~m}^{-2} \mathrm{~d}^{-1} \mathrm{kPa}^{-1}\right)$ as follows:

$O P=O T R \times x$ where OTR was gained from the gas permeameter, and $\mathrm{x}$ is the film thinkness (m).

The thickness and open testing area of each sample in the three parallel measurements were approximately $100 \mu \mathrm{m}$ and $50 \mathrm{~cm}^{2}$.

\section{Total color difference $(\Delta \mathrm{E})$}

Color was determined for soy protein films with and without the addition of antimicrobial agents to provide background information for comparison with color of Nisin, sodium lactate, EDTA and their combination. Color was determined by NR10QC and recorded in L*a*b* color system. Measurements were taken as a average of at least three points of each sample. Total color difference $(\Delta \mathrm{E})$ was calculated as follows:

$$
\Delta E=\sqrt{\left(L^{*}-L\right)^{2}+(a *-a)^{2}+(b *-b)^{2}}
$$

where $L^{*}, a^{*}$ and $b^{*}$ are the standard values of white plate, $\mathrm{L}, \mathrm{a}$, and $\mathrm{b}$ are values of samples measured.

\section{Analysis on the FTIR}

At the Engineering College of Northeast Forestry University, China, the FTIR spectrometry (Nicolet Antaris II) at room temperature was applied to record the spectra of the SPI films (controlling and the three antimicrobial substances are incorporated). The light source of transmittance was in the middle range infrared between $600 \mathrm{~cm}^{-1}$ and $4000 \mathrm{~cm}^{-1}$. The detector used was triglycine sulfate (TGS) with the resolution $4 \mathrm{~cm}^{-1}$. The gained spectra was applied to recognize the potential interactions of the function groups among SPI and Nisin, sodium lactate and EDTA.

\section{Application experiment Sample processing}

The method for sample processing was a modified procedure as used by Zhao (2013).

Take fresh pork tenderloin and divide it into about $40 \mathrm{~g}$ small pieces in good health conditions. Then packaging them with prepared SPI antimicrobial film [N (5000 IU/g $\mathrm{SPI})+\mathrm{NaL}(1.0 \mathrm{~g} / \mathrm{g} \mathrm{SPI})+\mathrm{EDTA}(0.08 \mathrm{~g} / \mathrm{g} \mathrm{SPI})]$ and pure SPI film. The control group was a meat sample packaged with only ordinary wraps. All samples were placed in the refrigerator at $4^{\circ} \mathrm{C}$ for 24 hours. After that, the indicators were measured every day until samples are corrupt.

\section{Determination of total bacterial count}

The total bacterial count was determined according to Devlieghere et al. (2005).

\section{Determination of total volatile basic nitrogen (TVB-N) value}

Using Kjeldahl method to measure the TVB-N value of sample (Cheng et al., 2014). 


\section{Statistical analysis}

All experiments were performed at least three times. All data were presented as means \pm standard error of the mean. As for multiple group comparison, the significance of the differences among the treatment groups and their respective control groups were analyzed using origin 8.5 and SPSS 17.0 software. Statistical significance was assessed by either student's t-test or one-way analysis of variance (ANOVA) followed by Duncan's multiple comparison. Differences between means were considered statistically significant if $\mathrm{p}<0.05$.

\section{RESULTS AND DISCUSSION}

Nisin, NaL and EDTA were found effective to fight against food-borne pathogens. Nevertheless, when these compounds are applied singly, they would be not adequate as a protection against food-borne pathogens. Presently, it was further studied that their combination into SPI film-forming solutions as a multiple hurdle approach against major food-borne pathogens, including E. coli (G-), S. typhimurium (G-), and B. cereus $\left(\mathrm{G}^{+}\right)$and their effect on the mechanical properties of the SPI edible films.

\section{Antimicrobial activity}

Table 1 and (Fig. 1a-c) showed the antimicrobial activity of the SPI edible films, combined with N, NaL, EDTA and their combination against E. coli (G-), Salmonella (G-), and
B. cereus $\left(\mathrm{G}^{+}\right)$. These three pathogens are also known as the ordinary meat products contaminants. According to the clear zone (Fig. 1), the inhibitory activity can be measured based on the strips of the circular film.

The values of inhibition zones were always higher than $20 \mathrm{~mm}$, which was the diameter of the film strips, because the value included the diameter. Without surrounding clear zone, there would be no inhibitory zone. And the value would be defined as zero. The contact area was used to evaluate the growth inhibition under film discs in direct contact with target microorganisms in agar.

The control SPI film did not show inhibitory effect against three tested microorganisms in terms of no surrounding clear zone for the no inhibition nature of SPI molecules. The SPI film incorporating $\mathrm{N}$ showed an antimicrobial effect. The inhibitory zone were markedly high against B.cereus $\left(\mathrm{G}^{+}\right)$at the lowest level of $5000 \mathrm{IU} / \mathrm{g}$ SPI and the value is $29.58 \mathrm{~mm}$. But it did not show inhibitory zone on E.coli (G-) and Salmonella (G-). It is to be expected as the cell war structures of these categories of bacteria are different and Gram-positive bacteria are more sensitive to these agents. However, the N-incorporated SPI film showed an inhibitory effect on the growth underneath film discs of these organisms. Higher level of $\mathrm{N}$ adding to the SPI films than $5000 \mathrm{IU} / \mathrm{g}$ SPI did not revealed a significant increased antimicrobial effect, which may probably due

Table 1: Antimicrobial activity of SPI edible films containing Nisin, sodium lactate (NaL) and EDTA against food pathogenic bacteria of E. coli, Salmonella and B.cereus

\begin{tabular}{|c|c|c|c|c|c|c|}
\hline \multirow[t]{2}{*}{ Antimicrobial agents } & \multicolumn{2}{|c|}{ E. coli (G-) } & \multicolumn{2}{|c|}{ Salmonella (G-) } & \multicolumn{2}{|c|}{ B.cereus (G+) } \\
\hline & Inhibitory & Contact & Inhibitory & Contact & Inhibitory & Contact \\
\hline Control & $0^{f}$ & - & $0^{f}$ & - & $0^{i}$ & - \\
\hline \multicolumn{7}{|l|}{ Nisin (103 IU/g SPI) } \\
\hline 5 & $0^{f}$ & + & $0^{f}$ & \pm & $29.58 \pm 0.77^{b}$ & \pm \\
\hline 10 & $0^{f}$ & \pm & $0^{f}$ & \pm & $29.31 \pm 1.55^{b}$ & + \\
\hline 15 & $0^{f}$ & + & $0^{f}$ & \pm & $26.83 \pm 1.84^{c}$ & + \\
\hline 20 & $0^{f}$ & + & $0^{f}$ & + & $26.97 \pm 0.58^{c}$ & + \\
\hline \multicolumn{7}{|l|}{$\mathrm{NaL}$ (g/g SPI) } \\
\hline 0.5 & $28.50 \pm 1.63^{b}$ & + & $27.00 \pm 1.22^{\mathrm{bc}}$ & + & $20.83 \pm 0.59^{h}$ & \pm \\
\hline 1.0 & $28.50 \pm 1.47^{b}$ & \pm & $26.67 \pm 1.03^{c}$ & + & $23.48 \pm 3.00^{\mathrm{de}}$ & \pm \\
\hline 1.5 & $26.36 \pm 1.51^{c}$ & + & $27.00 \pm 1.22^{\mathrm{bd}}$ & + & $22.72 \pm 1.26^{g}$ & \pm \\
\hline 2.0 & $26.00 \pm 2.48^{c}$ & + & $25.17 \pm 1.42^{\mathrm{e}}$ & + & $23.00 \pm 4.24^{\mathrm{fg}}$ & \pm \\
\hline \multicolumn{7}{|l|}{ EDTA (g/g SPI) } \\
\hline 0.04 & $23.00 \pm 0.41^{e}$ & \pm & $27.00 \pm 1.22 b^{c}$ & + & $23.72 \pm 0.97^{d}$ & \pm \\
\hline 0.08 & $25.72 \pm 1.59^{c}$ & \pm & $27.44 \pm 1.13^{b}$ & + & $23.17 \pm 0.24^{\text {efg }}$ & + \\
\hline 0.12 & $24.33 \pm 1.25^{d}$ & \pm & $26.67 \pm 1.03^{c}$ & + & $23.22 \pm 0.87^{\text {ef }}$ & + \\
\hline 0.16 & $23.33 \pm 0.98^{e}$ & + & $27.19 \pm 2.76^{b}$ & + & $23.94 \pm 1.4^{d}$ & \pm \\
\hline 0.20 & $23.33 \pm 0.85^{e}$ & + & $25.89 \pm 0.96^{d}$ & + & $23.89 \pm 1.84^{d}$ & \pm \\
\hline \multicolumn{7}{|c|}{$\begin{array}{l}\text { Nisin }(5000 \mathrm{IU} / \mathrm{g} \mathrm{SPI})+\mathrm{NaL}(1.0 \mathrm{~g} / \mathrm{g} \mathrm{SPI})+E D T A(0.08 \mathrm{~g} / \mathrm{g} \\
\mathrm{SPI})\end{array}$} \\
\hline & $32.00 \pm 2.04^{\mathrm{a}}$ & + & $33.33 \pm 0.62^{a}$ & + & $32.33 \pm 0.62^{\mathrm{a}}$ & + \\
\hline
\end{tabular}

${ }^{a-i}$ Mean \pm standard deviation $(n=3)$. Means in same column with different superscript letters are significantly different ( $\left.p<0.05\right)$. Inhibitory is inhibitory zone surrounding film discs, measured diameter in $\mathrm{mm}$; contact is contact area under film discs on agar surface. - indicates growth in the area, + indicates no growth; control is a plain film disc without antimicrobial agent incorporation 
to the maximum capability of SPI polymer to carry active agents beside the occurrence of functional groups interaction(Pranoto et al., 2005). Bari et al. (2005) had demonstrated that $\mathrm{N}$ and some organic acids can be used as antimicrobials in foods at lower levels without diminishing their inhibitory effects. As shown in Table. 1 and Fig. 1-b, SPI films incorporated with $\mathrm{NaL}$ had a relatively stable antimicrobial properties against E.coli (G-), Salmonella (G-) and B.cereus $\left(\mathrm{G}^{+}\right)$. And at the level of $1.0 \mathrm{~g} / \mathrm{g}$ SPI the addition of $\mathrm{NaL}$ showed a relatively high inhibitory effect against three micorganisms. The inhibitory effect of NaLincorporated SPI films on B.cereus $(\mathrm{G}+)$ were significantly $(\mathrm{p}<0.05)$ lower than the $\mathrm{N}$-incorporated SPI films. So the $\mathrm{NaL}$ could make up the shortage of $\mathrm{N}$-incorporated SPI films which could not inhibit the G- bacteria. The SPI film incorporated with EDTA showed a little antimicrobial activity against three pathogens. The inhibitory effect of EDTA on bacteria may probably be contributed to the chelation of divalent cations found in the cell war (Ukuku and Fett, 2004).

However, the SPI films incorporated with the combination of $\mathrm{N}, \mathrm{NaL}$ and EDTA had a significant $(\mathrm{p}<0.05)$ antimicrobial effect against E.coli (G-), Salmonella (G-) and B.cereus $\left(\mathrm{G}^{+}\right)$, inhibitory zone from $28.50 \mathrm{~mm}(0.5$, $1.0 \mathrm{~g} \mathrm{NaL} / \mathrm{g} \mathrm{SPI}), 27.44 \mathrm{~mm}(0.08 \mathrm{~g}$ EDTA/g SPI $)$ and $29.58 \mathrm{~mm}(5000 \mathrm{IU} \mathrm{N} / \mathrm{g} \mathrm{SPI}$ ) to $32.00 \mathrm{~mm}, 33.33 \mathrm{~mm}$ and $32.33 \mathrm{~mm}$. Branen and Davidson(2004), Kun

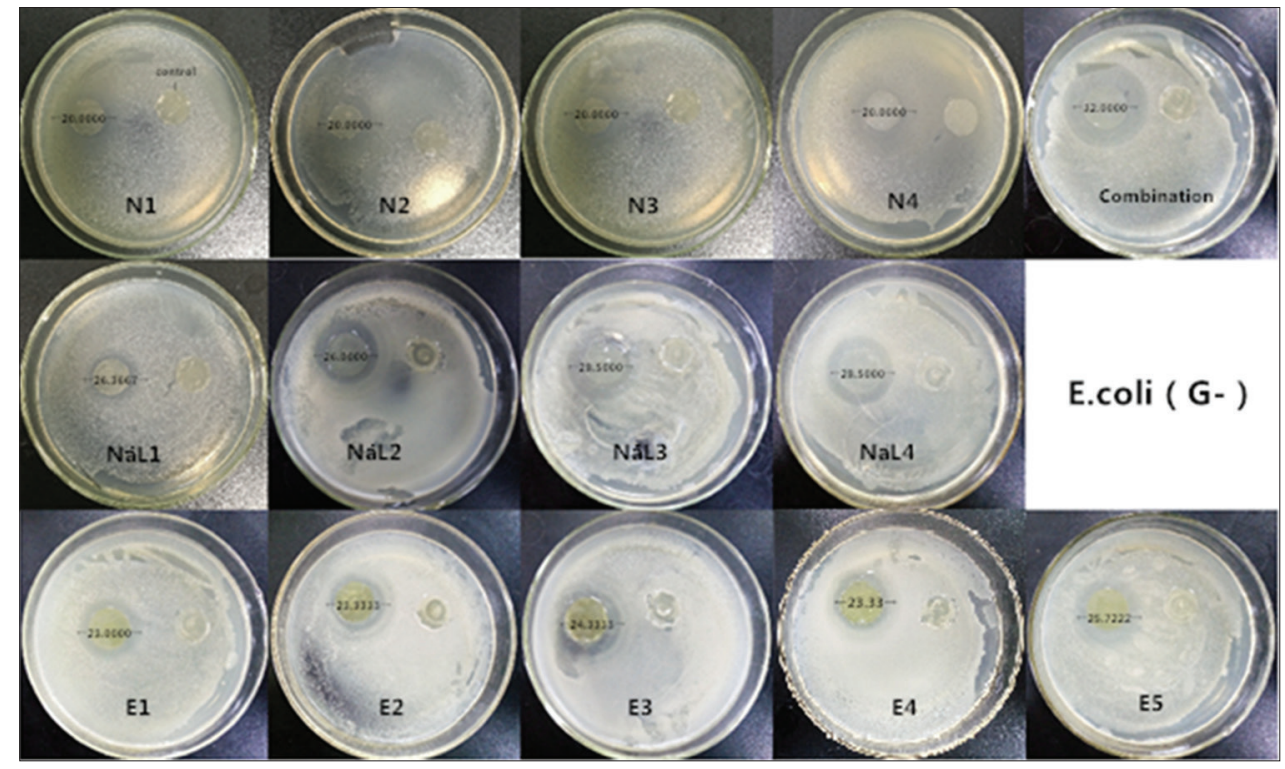

Fig 1-a. Inhibitory zone of SPI edible films containing Nisin, sodium lactate and EDTA against food pathogenic bacteria of E.coli (G-).

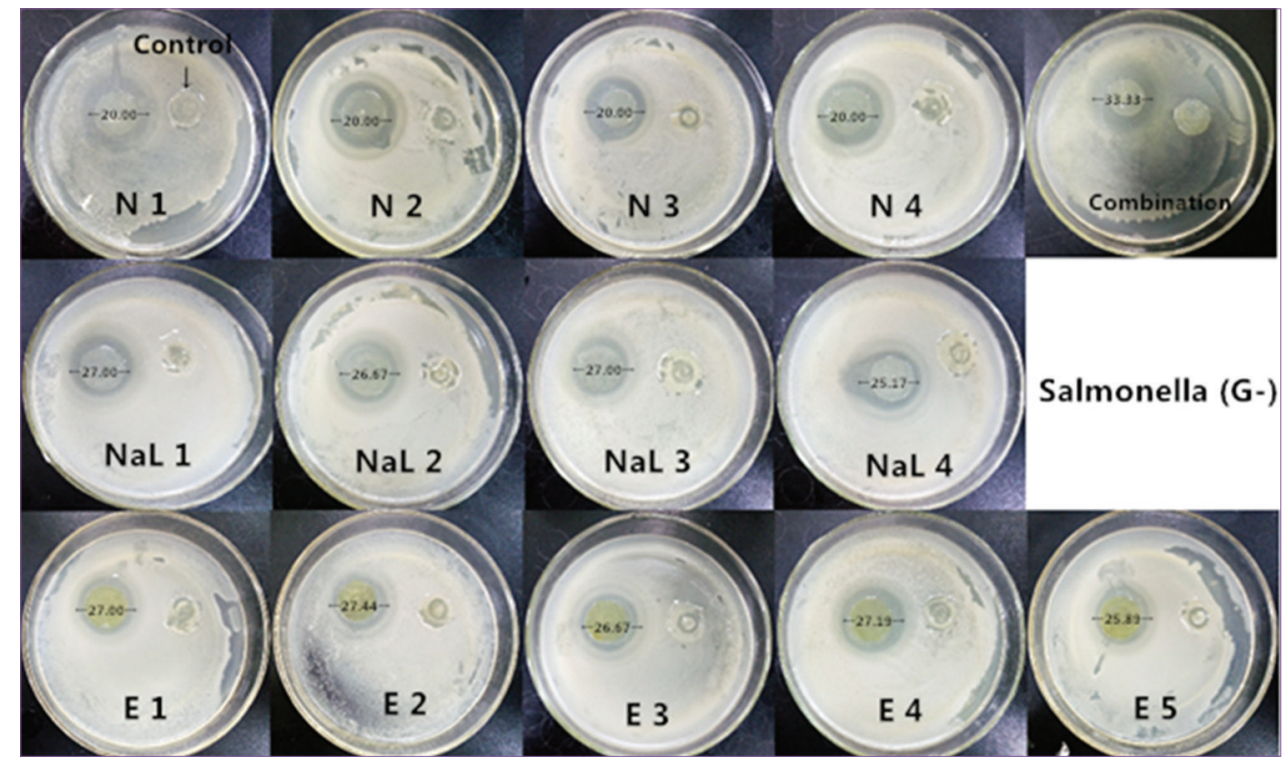

Fig 1-b. Inhibitory zone of SPI edible films containing Nisin, sodium lactate and EDTA against food pathogenic bacteria of Salmonella (G-). 


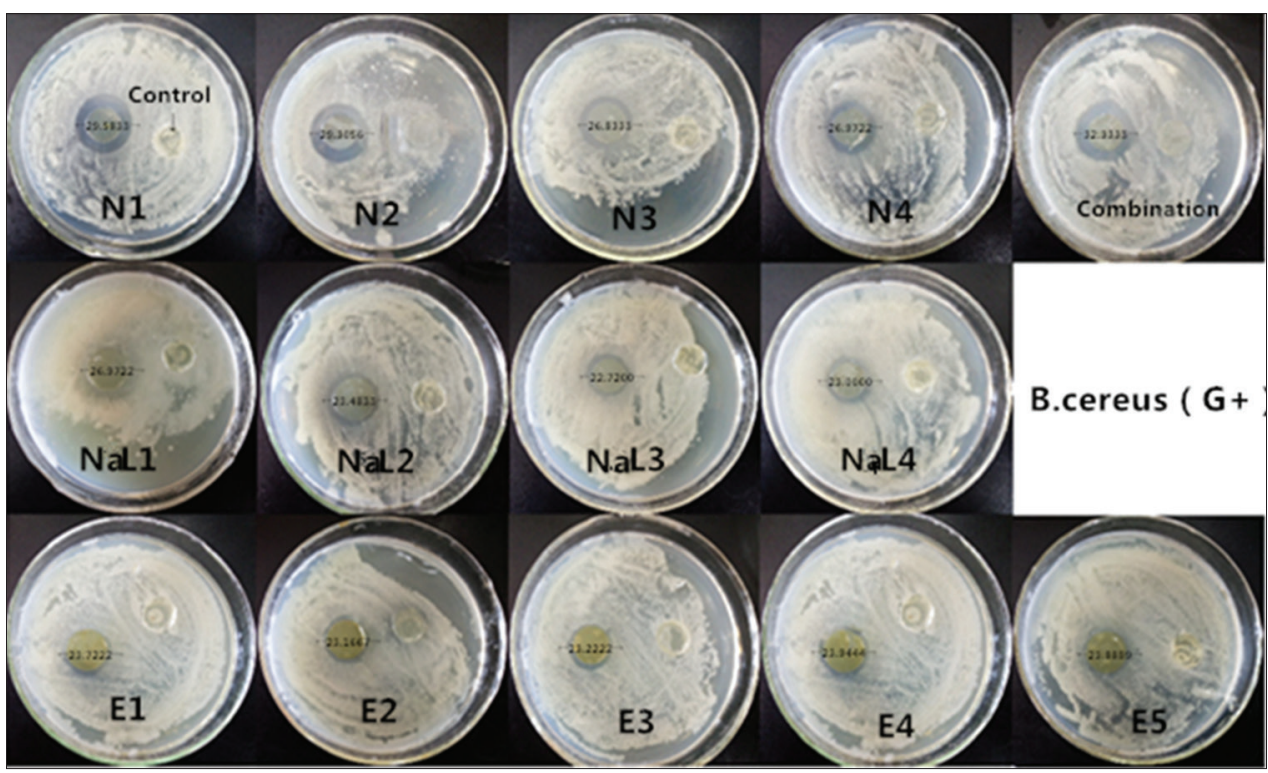

Fig 1-c. Inhibitory zone of SPI edible films containing Nisin, sodium lactate and EDTA against food pathogenic bacteria of B.cereus (G+).

(2012) and Yun et al. (2006) have demonstrated that the antimicrobial activity of $\mathrm{N}$ can be enhanced in the combination with EDTA. Ukuku and Fett (2004) reported that treatment of whole and fresh-cut cantaloupe and honeydew melon with N-EDTA significantly reduced the natural microflora and extended the shelf-life and that $\mathrm{N}$ in combination with $\mathrm{NaL}$, EDTA caused a significant reduction of Salmonella app. population the pathogen transferred to fresh-cut pieces during cutting. EDTA might enhance the activity of $\mathrm{N}$ and $\mathrm{NaL}$ against these pathogens by chelating with the macro-molecules such as salt bridge divalent cations between lipo-polysaccharides on the cell membrane and destroying the stability of the bacterial cell (Vaara et al., 1999). So as to increase hydrophobic interactions between $\mathrm{N}$ or $\mathrm{NaL}$ and cell membrane (Yang et al., 2002).

\section{Physical properties of SPI-based films}

During handling and storage, it is expected that the edible SPI films have adequate strength and maintain constant integrity on the food products (Sivarooban et al., 2008). And the interaction between protein and other additives, including water, plasticizers and antimicrobial agents determined the mechanical and physical properties of SPIbased films (Park et al., 2002).The interaction of SPI and plasticizer which is glycerol here had an important effect on the mechanical properties of SPI-based film.

\section{Mechanical properties}

The formation of the protein film results from polymerizing the heat-denatured proteins with disulfide and hydrophobic bonds which are the main forces that can maintain the film network (Fukushima and Buren, 1970). Also, the electrostatic interaction between protein molecules and antimicrobial agents which can form the film network is possible to have resulted into the mechanical change of films (Ko et al., 2001).

The Mechanical properties of SPI-based films are shown in Table 2.

In the different concentration of antimicrobial agents studied, a significant $(p<0.05)$ reduction of TS was shown by incorporating $\mathrm{N}$ and $\mathrm{NaL}$ compared with EDTA. Incorporating $\mathrm{NaL}$ at the level of $1.5 \mathrm{~g} / \mathrm{g}$ SPI significantly $(\mathrm{p}<0.05)$ reduced TS from 10.8716 to $3.2715 \mathrm{MPa}$, while with $\mathrm{N}$ at $5000 \mathrm{IU} / \mathrm{g}$ SPI reduced it from 10.8716 to 8.1405 $\mathrm{MPa}$. The results are consistent with the outcome of the report by Cagri et al. (2001), who had concluded earlier that incorporation of additives other than cross-linking agents generally lowers TS value.

However, a significant $(\mathrm{p}<0.05)$ improvement of TS was revealed by addition of EDTA at the level of $0.16 \mathrm{~g} / \mathrm{g}$ SPI that raised TS value from 10.8716 to $17.0600 \mathrm{MPa}$. And the addition of the combination of three antimicrobial agents improved the TS value of SPI-based films from 10.8716 to $15.0834 \mathrm{MPa}$. The improvement of the TS value may be attributed to the addition of EDTA. It probably be due to the cross linking reactions between EDTA and the macromolecules in the SPI film (Singh et al., 2012).

The addition of $\mathrm{N}$ and EDTA in the concentrations studied and the combination of three antimicrobial agents into the SPI-based films didn't have a significant $(p<0.05)$ effect on the $\mathrm{E}$ value of the films (Table 2). However, incorporating $\mathrm{NaL}$ in the range of concentrations studied significantly $(p<0.05)$ increased $E$ value from $3.03 \%$ to $11.21 \%$, about 


\begin{tabular}{|c|c|c|c|c|c|}
\hline Antimicrobial agents & TS (MPa) & $E(\%)$ & WVP $\left(\mathrm{gm} / \mathrm{m}^{2}\right.$ daykPa) & OP $\left(\mathrm{cm}^{3} \mathrm{~m}^{-2} \mathrm{~d}^{-1} \mathrm{kPa}^{-1}\right)$ & $\Delta \mathrm{E}$ \\
\hline Control & $10.8716 \pm 1.3481^{e}$ & $3.03 \pm 1.50^{k}$ & $0.0116 \pm 1.06 \times 10^{-3 j}$ & $0.0052 \pm 0.99 \times 10^{-3 e}$ & $7.01 \pm 0.01^{\prime}$ \\
\hline \multicolumn{6}{|l|}{ Nisin (103 IU/g SPI) } \\
\hline 5 & $8.1405 \pm 2.5356^{j}$ & $4.24 \pm 2.31^{\mathrm{h}}$ & $0.03701 \pm 1.17 \times 10^{-3 h}$ & $0.0055 \pm 0.21 \times 10^{-3 e}$ & $7.28 \pm 0.02^{k}$ \\
\hline 10 & $9.4105 \pm 3.1479^{h}$ & $4.52 \pm 1.59 \mathrm{~g}$ & $0.04012 \pm 1.06 \times 10^{-3 g}$ & $0.0070 \pm 0.31 \times 10^{-3 d}$ & $9.90 \pm 0.12^{\mathrm{g}}$ \\
\hline 15 & $9.9602 \pm 4.5670^{g}$ & $4.73 \pm 1.80^{f}$ & $0.04713 \pm 0.16 \times 10^{-3 d}$ & $0.0082 \pm 0.21 \times 10^{-3 c d}$ & $7.28 \pm 0.10^{k}$ \\
\hline 20 & $8.2794 \pm 4.6685^{i}$ & $4.73 \pm 2.38^{f}$ & $0.0487 \pm 0.09 \times 10^{-3 c}$ & $0.0085 \pm 0.67 \times 10^{-3 c}$ & $6.01 \pm 0.07^{\mathrm{m}}$ \\
\hline \multicolumn{6}{|l|}{$\mathrm{NaL}$ (g/g SPI) } \\
\hline 0.5 & $6.3902 \pm 2.2749^{k}$ & $7.97 \pm 0.10^{d}$ & $0.0431 \pm 0.16 \times 10^{-3 f}$ & $0.0071 \pm 0.21 \times 10^{-3 d}$ & $8.14 \pm 1.21^{h}$ \\
\hline 1.0 & $4.3799 \pm 1.3443^{\prime}$ & $8.73 \pm 0.59^{c}$ & $0.0437 \pm 0.32 \times 10^{-3 e}$ & $0.0073 \pm 0.25 \times 10^{-3 d}$ & $6.95 \pm 1.47$ \\
\hline 1.5 & $3.2715 \pm 2.0850^{n}$ & $10.27 \pm 1.74^{b}$ & $0.0626 \pm 0.06 \times 10^{-3 b}$ & $0.0098 \pm 1.27 \times 10^{-3 b}$ & $8.01 \pm 0.65^{i}$ \\
\hline 2.0 & $3.8586 \pm 4.2358^{\mathrm{m}}$ & $11.21 \pm 0.81^{a}$ & $0.0728 \pm 0.38 \times 10^{-3 a}$ & $0.0125 \pm 1.50 \times 10^{-3 a}$ & $7.80 \pm 0.93^{j}$ \\
\hline \multicolumn{6}{|l|}{ EDTA (g/g SPI) } \\
\hline 0.04 & $11.7894 \pm 4.5592^{d}$ & $2.36 \pm 1.09$ & $0.0095 \pm 0.80 \times 10^{-3 k}$ & $0.0047 \pm 0.35 \times 10^{-3 e f}$ & $24.21 \pm 3.35^{e}$ \\
\hline 0.08 & $15.4586 \pm 9.0313^{b}$ & $3.21 \pm 1.15^{j}$ & $0.0074 \pm 0.04 \times 10^{-31}$ & $0.0037 \pm 0.30 \times 10^{-3 \mathrm{tg}}$ & $29.64 \pm 3.48^{b}$ \\
\hline 0.12 & $10.6509 \pm 1.2867^{\dagger}$ & $3.03 \pm 0.53^{k}$ & $0.0062 \pm 0.07 \times 10^{-3 \mathrm{~m}}$ & $0.0033 \pm 3.2 \times 10^{-39}$ & $30.34 \pm 4.44^{\mathrm{a}}$ \\
\hline 0.16 & $17.0600 \pm 4.5251^{\mathrm{a}}$ & $4.24 \pm 1.02^{\mathrm{h}}$ & $0.0059 \pm 0.59 \times 10^{-3 n}$ & $0.0029 \pm 2.5 \times 10^{-3 g}$ & $25.86 \pm 3.10^{d}$ \\
\hline 0.20 & $15.1317 \pm 2.7445^{c}$ & $3.85 \pm 0.23^{i}$ & $0.0052 \pm 0.15 \times 10^{-30}$ & $0.0026 \pm 0.26 \times 10^{-3 g}$ & $28.10 \pm 6.72^{\circ}$ \\
\hline \multicolumn{6}{|c|}{$\begin{array}{l}\text { Nisin }(5000 \mathrm{IU} / \mathrm{g} \mathrm{SPI})+\mathrm{NaL}(1.0 \mathrm{~g} / \mathrm{g} \\
\text { SPI)+EDTA (0.08 g/g SPI) }\end{array}$} \\
\hline & $15.0834 \pm 1.4672^{c}$ & $5.42 \pm 0.46^{e}$ & $0.0205 \pm 0.85 \times 10^{-3 i}$ & $0.0050 \pm 0.26 \times 10^{-3 e}$ & $12.07 \pm 2.10^{f}$ \\
\hline
\end{tabular}

${ }^{a-0}$ Mean \pm standard deviation $(n=3)$. Means in same column with different superscript letters are significantly different $(p<0.05)$

four times. The result was probably due to the special properties of $\mathrm{NaL}$, similar to the glycerol, as a slightly viscous liquid (Cui, 2009). The incorporating of $\mathrm{NaL}$ into the SPI-based film may cause the rearrangement of the disulfide and hydrophobic bonds or more protein-protein interactions, which both result the E value of SPI films increased significantly $(p<0.05)$ (Chao et al., 2013). Choi et al. (2001) reported that increasing the concentration of glycerol in the film decreased tensile strength and elastic modulus, and increased elongation and water vapor permeability (WVP).

\section{Barrier properties}

Water vapor permeability (WVP) and oxygen permeability $(\mathrm{OP})$ is the barrier properties of SPI-based films.

WVP is used to measure the ease of moisture to penetrate and pass through a material (Pranoto et al., 2005). Permeability, depending on the composition and the molecular structure of the filmogenic matric, may be a complex phenomenon (Li et al., 2015).

The addition of $\mathrm{N}$ and NaL significantly $\quad(\mathrm{p}<0.05)$ increased the WVP value from $0.0116 \mathrm{gm} / \mathrm{m}^{2}$ day $\mathrm{kPa}$ to around $0.0487 \mathrm{gm} / \mathrm{m}^{2}$ daykPa (20000 IU N/g SPI) and $0.0728 \mathrm{gm} / \mathrm{m}^{2}$ daykPa $(2.0 \mathrm{~g} \mathrm{NaL} / \mathrm{g} \mathrm{SPI})$, respectively (Table 2). It can be seen that higher agents of $\mathrm{N}$ and $\mathrm{NaL}$ could lead to increasing the WVP value. The result is consistent with the conclusion of Roy et al. (2000). and Diop (2011), who reported that the natural materials are hydrophilic materials with polar groups in their molecular structures and the interactions of the polar groups with permeating water molecules causes the WVP to depart from the ideal behavior. However, the WVP value of the SPI film decreased as the concentration of the EDTA was higher from $0.0116 \mathrm{gm} / \mathrm{m}^{2}$ daykPa to $0.0052 \mathrm{gm} / \mathrm{m}^{2}$ daykPa (0.20 g EDTA/g SPI). The EDTA, as a hydrophobic chelating agent, increased hydrophobic composition in the SPI-based films (Diop, 2011) and cause the film structure to be more compact, thus making the WVP value decreased. The combination of bacteriostatic agent increased slightly the WVP value from $0.0116 \mathrm{gm} / \mathrm{m}^{2}$ daykPa to $0.0205 \mathrm{gm} /$ $\mathrm{m}^{2}$ daykPa. The result is coherent with Yong et al. (2007), who concluded that increasing the flexibility of the material, plasticizers generally contribute to the increase of gas and WVP of films. Relatively low WVP value of SPI-based films contributes to the antibacterial properties of the packaging film (Chen, 2010).

Oxygen permeability (OP) of food packaging is generally considered since it related to the development of offfavors, off-odors and nutritional loss associated with oxidation in food stuffs (Ozdemir and Floros, 2005). It means that lower oxygen permeability (OP) of films is better (Ou and Kwok, 2004). As could be seen from Table 2, the OP and WVP value of films were positively correlated. Similar to WVP, the OP values of SPI-based films incorporating $\mathrm{N}$ and $\mathrm{NaL}$ had significantly $(\mathrm{p}<0.05)$ increased, from 0.0052 to 0.0085 (20000 IU N/g SPI) and $0.0125 \mathrm{~cm}^{3} \mathrm{~m}^{-2} \mathrm{~d}^{-1} \mathrm{kPa}^{-1}(2.0 \mathrm{~g} \mathrm{NaL} / \mathrm{g} \mathrm{SPI})$, respectively. However, the OP value of the SPI-based films was decreased as the addition of EDTA, from $0.0052 \mathrm{~cm}^{3}$ 
$\mathrm{m}^{-2} \mathrm{~d}^{-1} \mathrm{kPa}^{-1}$ to $0.0026 \mathrm{~cm}^{3} \mathrm{~m}^{-2} \mathrm{~d}^{-1} \mathrm{kPa}^{-1}$ (0.20 g EDTA/g $\mathrm{SPI}$ ), and the OP value was decreased as the concentration of EDTA was higher. The OP value of SPI-based film incorporating with the combination of three antimicrobial agents is similar to the value in the pure SPI film, which is $0.0052 \mathrm{~cm}^{3} \mathrm{~m}^{-2} \mathrm{~d}^{-1} \mathrm{kPa}^{-1}$ (Table 2).

\section{Color difference $(\Delta E)$}

Color of the films is essential for a product, which may affect the consumer acceptability. From the $\Delta \mathrm{E}$ value, it can be seen that the color is totally different which was formulated by $a, L$ and $b$ values, representing green to red, black to white and blue to yellow. The color reference should be the white plate. Rhim et al. (2000) said that various of the additional compounds structurally bind with the film-forming solution which could make the native color of the soy protein film change. The color of the SPI films incorporating N, NaL, EDTA, and their combination were evaluated. As seen in Table 2, the $\mathrm{N}$ and EDTA within the concentration studied influenced significantly $(\mathrm{p}<0.05)$ the color of SPI films compared with the control (Table 2). As the antimicrobial agents were incorporated into the films, its transparency was reduced. The value of pure SPI film was 7.01. And the SPI-based films incorporated with $\mathrm{NaL}$ did not significantly $(\mathrm{p}<0.05)$ change the $\Delta \mathrm{E}$ value. The $\mathrm{N}$ and EDTA affected $\Delta \mathrm{E}$ of the SPI film produced. The EDTA incorporating into SPI film at $0.04 \mathrm{~g} / 200 \mathrm{ml}$ had a significant influence on $\Delta \mathrm{E}$ value already, which increased the $\Delta \mathrm{E}$ from 7.01 to 30.34 (0.12 g/g SPI) (Table 2). The incorporation of their combination into the SPI film reduced the effect of EDTA on color of SPI-based films, reducing from 30.34 to 12.07 .

\section{FTIR Analysis}

The interaction between the antimicrobial agents and SPI have been studied using FTIR. Figs. 2 a-c showed the SPI films spectrum incorporating with different antimicrobial agents at varying levels in the study. All of the spectrum demonstrate the patterns sharing similarity when it peaks at $3269.75 \mathrm{~cm}^{-1}$ and $1041.73 \mathrm{~cm}^{-1}$. It is indicated according to the absorption in this area that $\mathrm{O}-\mathrm{H}$ and $\mathrm{N}-\mathrm{H}$ bonds are stretched at $3269 \mathrm{~cm}^{-1}$, and C-O bonds at $1041 \mathrm{~cm}^{-1}$. Also, the absorption gains the highest at $2928 \mathrm{~cm}^{-1}, 1625$ $\mathrm{cm}^{-1}$, and $1550 \mathrm{~cm}^{-1}$ which are correspondent to the $\mathrm{C}-\mathrm{H}$ stretching, carboxyl groups (-COO-), as well as an amine group $\left(-\mathrm{NH}_{2}\right)$. The above mentioned indicates that major structural changes do not take place in the SPI polymer.

Figs. 2-a depicts the spectrum of the control SPI film and the films incorporated $\mathrm{N}$ at varying levels used in the study. The spectrum of control film and antimicrobial films incorporated with $\mathrm{N}$ showed the same pattern on their informative peaks as the control film (Theinsathid et al., 2011). As expected, this behaviour could be considered

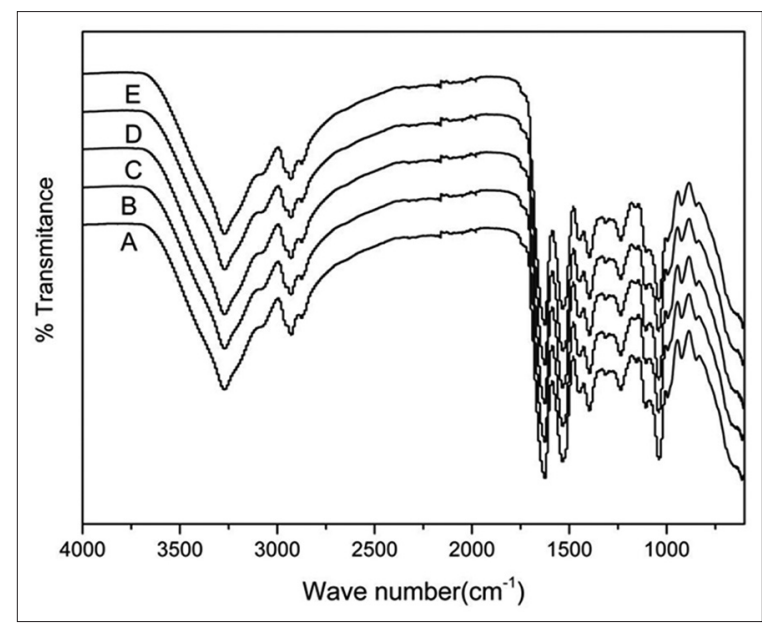

Fig 2-a. Spectra of Fourier Transform Infrared (FTIR) of SPI edible films. (A) SPI film,(B) SPI film incorporated with nisin $5000 \mathrm{IU} / \mathrm{g} \mathrm{SPI}$, (C) SPI film incorporated with nisin $10000 \mathrm{IU} / \mathrm{g} \mathrm{SPI}$, (D) SPI film incorporated with nisin $15000 \mathrm{IU} / \mathrm{g} \mathrm{SPI}$, (E) SPI film incorporated with nisin $20000 \mathrm{lU} / \mathrm{g} \mathrm{SPI}$.

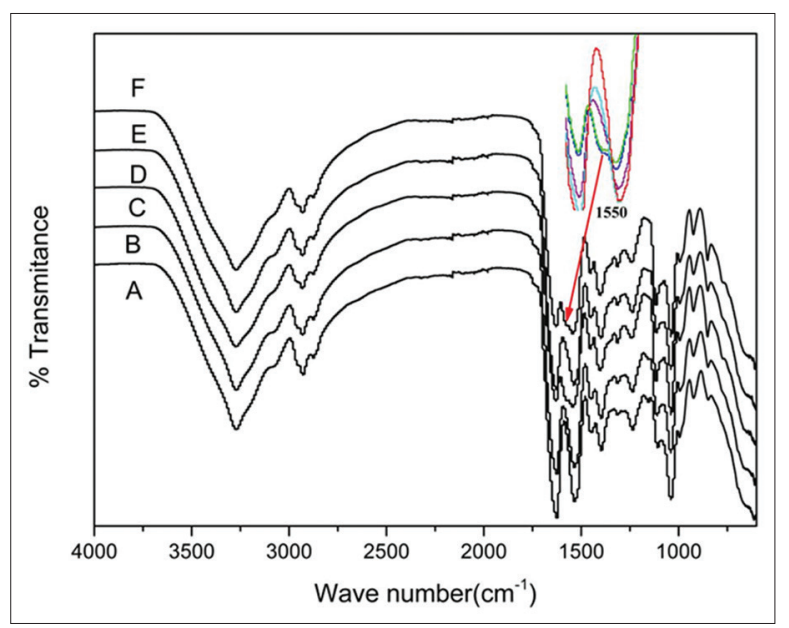

Fig 2-b. Spectra of Fourier Transform Infrared (FTIR) of SPI edible films. (A) SPI film,(B) SPI film incorporated with sodium lactate $0.5 \mathrm{~g} / \mathrm{g}$ SPI, (C) SPI film incorporated with sodium lactate $1 \mathrm{~g} / \mathrm{g} \mathrm{SPI}$, (D) SPI film incorporated with sodium lactate $1.5 \mathrm{~g} / \mathrm{g} \mathrm{SPI}$, (E) SPI film incorporated with sodium lactate $2 \mathrm{~g} / \mathrm{g}$ SPI.

to be no specific interaction between active groups of $\mathrm{N}$ with functional group of SPI. Similar scheme was presented by Liu et al. (2010). However, the result is different from Shiroodi et al. (2016). They reported that the peak indensity of whey protein isolate (WPI)-based and pea protein isolate (PPI)-based films increased as the concentration of $\mathrm{N}$ higher. The difference between the results may be due to the physical and chemical difference in the matrix, which is WPI, PPI, and SPI.

Fig. 2-b showed the spectrum of the control SPI films and the films incorporated $\mathrm{NaL}$ at different levels. The indensity of peaks in SPI-NaL films was slightly increased. And as we can seen from Fig 2-b, there is a change in the amide I 
band at $1550 \mathrm{~cm}^{-1}$ appears obviously. Absorption peak at $1550 \mathrm{~cm}^{-1}$ was assigned to the stretching vibration of $\mathrm{C}=\mathrm{C}$.

Figs. 2-c depicts the spectrum of the control SPI film and the films incorporated EDTA (E) at varying levels used in the study. Similar to the spectrum of SPI-NaL films, the intensity of peaks was increased. In the SPI-based films the intensity of peaks increase in amide I,II, III regions, indicating immobilization of $\mathrm{NaL}$ and EDTA onto film surface (Shiroodi et al., 2016). The increase was more significant as the concentration of EDTA higher. At the level of $0.2 \mathrm{~g}$ EDTA/g SPI, there were obvious peaks at $1358 \mathrm{~cm}^{-1}$ and $1183 \mathrm{~cm}^{-1}$, indicating the interaction between EDTA and SPI.

The SPI films are characterized by its mechanical and antimicrobial properties when they are incorporated with three antimicrobial agents, which were supported by the FITR infrared spectral data. When SPI films were incorporated with $\mathrm{N}$, and the SPI functional groups would have no modification. Thus, the mechanical properties have no significant changes. When the hydroxyl groups and conjugated double bonds are available in the reactive groups, the efficacy of the natural extracts can be determined on the pathogen inhibition. The active compound of $\mathrm{N}$ freely inhibits the microorganisms in the antimicrobial test (Pranoto et al., 2005; Wang et al. 2015). Relatively, the incorporation of NaL and EDTA into the SPI film had a significant effect on the functional group's change of the SPI film. Therefore, they changed much on the mechanical properties of SPI films produced but they did not show significant inhibitory effect caused by the unavailability of the free antimicrobial group.

\section{Application of experimental results analysis Total bacterial count of sample}

The total bacterial count of meat during storage is shown in Fig. 3-a. With the increase in storage time, the total bacterial count in each meat had been increasing (Fig. 3-a). Bacteria of the pure SPI film group were breeding very quickly that the samples wrapped by the pure SPI film group were corrupt earlier than the samples wrapped by the other two films. In the first three days the value of the total bacterial count of sample rose to $5.98 \mathrm{lg} \mathrm{cfu} / \mathrm{g}$, which means that the meat sample had become minor fresh meat, and to the $6^{\text {th }}$ day the total bacterial count value was $8.92 \mathrm{lg} \mathrm{cfu} / \mathrm{g}$, indicating the deterioration of the sample. While in the ordinary wraps group, the sample had been corrupt more than 3 days later. The total bacterial count of the sample wrapped by ordinary wraps was $4.78 \mathrm{lg} \mathrm{cfu} / \mathrm{g}$ on $3^{\text {rd }}$ day (Minor fresh), $5.98 \mathrm{lg}$ $\mathrm{cfu} / \mathrm{g}$ on $6^{\text {th }}$ day (Minor fresh), and $7.86 \mathrm{lg} \mathrm{cfu} / \mathrm{g}$ on $9^{\text {th }}$ day (Deterioration). There was a significant difference $(\mathrm{P}<0.05)$ between the SPI group and control group in the statistical analysis of total bacterial count of sample from the $3^{\text {rd }}$ day.

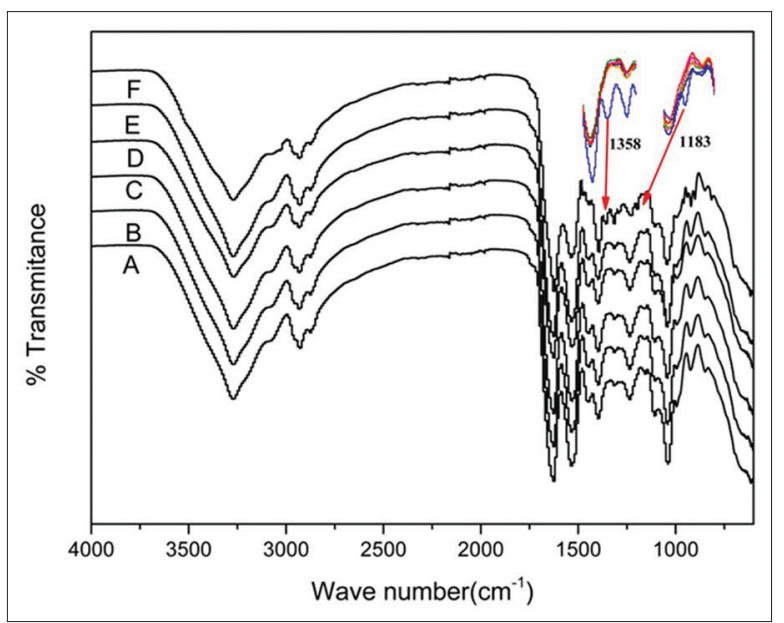

Fig 2-c. Spectra of Fourier Transform Infrared (FTIR) of SPI edible films.(A) SPI film, (B) SPI film incorporated with EDTA 0.04g/g SPI, (C) SPI film incorporated with EDTA $0.08 \mathrm{~g} / \mathrm{g}$ SPI, (D) SPI film incorporated with EDTA $0.12 \mathrm{~g} / \mathrm{g}$ SPI, (E) SPI film incorporated with EDTA $0.16 \mathrm{~g} / \mathrm{g}$ SPI, (F) SPI film incorporated with EDTA $0.2 \mathrm{~g} / \mathrm{g}$ SPI.

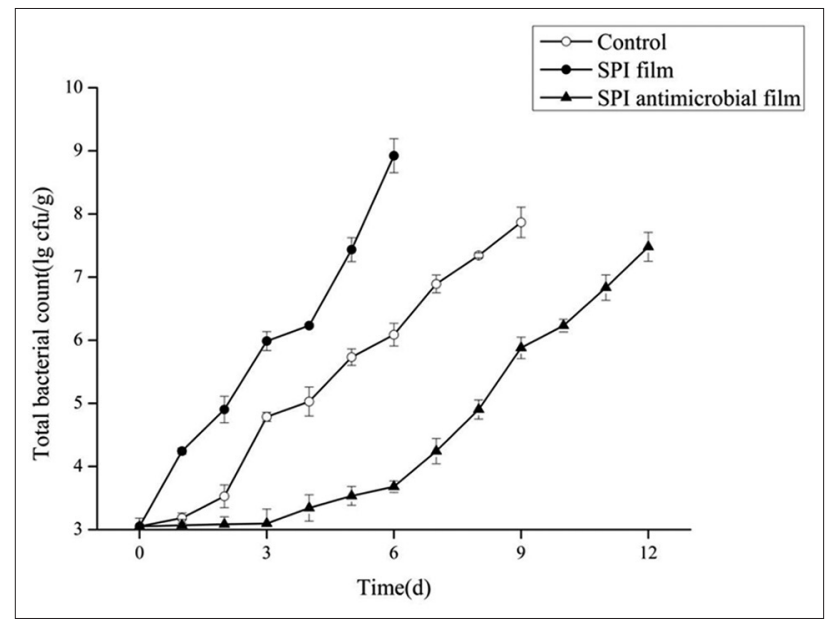

Fig 3-a. Evolution of total bacterial count during storage at $4^{\circ} \mathrm{C}$.

The total bacterial count of the sample wrapped by SPI antimicrobial film was $3.08 \mathrm{lg} \mathrm{cfu} / \mathrm{g}$ on $3^{\text {rd }}$ day (Fresh), 3.53 $\lg \mathrm{cfu} / \mathrm{g}$ on $6^{\text {th }}$ day (Fresh), $5.87 \mathrm{lg} \mathrm{cfu} / \mathrm{g}$ on $9^{\text {th }}$ day (Minor fresh) and $7.47 \mathrm{lg} \mathrm{cfu} / \mathrm{g}$ on $12^{\text {th }}$ day (Deterioration). The significant difference in the value of total bacterial count value between the sample of three groups indicating that the bacterial breeding speed of sample packaged with SPI antimicrobial films relatively slow, which was still in a freshness in the $9^{\text {th }}$ day. In short, it can be seen that the SPI antimicrobial film has a significant $(p<0.05)$ inhibitory effect on the beeding of bacteria during meat preservation.

\section{TVB- $N$ value of sample}

TVB-N value is the ammonia and amines and other nitrogen substances in the process of corruption and deterioration of protein due to animal foods' enzymes reacts with food surface micro-organisms, which is an important indicator of meat freshness (Duan, 2001). 


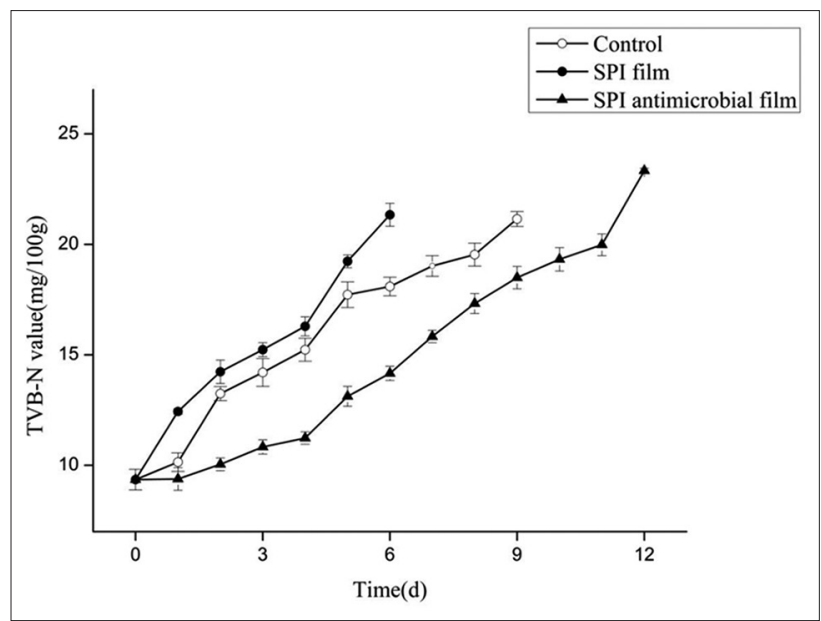

Fig 3-b. Evolution of TVB-N value during storage at $4^{\circ} \mathrm{C}$

As shown in Fig. 3-b, with the increase of the storage time, the TVB-N values of the meat samples showed an increasing trend. On the $3^{\text {rd }}$ day, the TVB-N values of the sample packaged with the pure SPI film, ordinary wraps and SPI antimicrobial film were 14.23, 14.20 and $10.83 \mathrm{mg} / 100 \mathrm{~g}$ on the $3^{\text {rd }}$ day, which means that the samples were in the first grade freshness and the sample of control group was the freshest. However, on the $6^{\text {th }}$ day the value of samples wrapped by the pure SPI film and ordinary wraps were 21.34 and $18.09 \mathrm{mg} / 100 \mathrm{~g}$, indicating that the sample in two groups were rotten and in second grade freshness respectively. On the $9^{\text {th }}$ day, the sample wrapped by ordinary wraps was rotten which TVB-N value was $21.15 \mathrm{mg} / 100 \mathrm{~g}$, whereas the sample of control group was still in second grade freshness (TVB-N value was $18.49 \mathrm{mg} / 100 \mathrm{~g}$ ). And the control group has become rotten on the $12^{\text {th }}$ day and its TVB-N value was $23.33 \mathrm{mg} / 100 \mathrm{~g}$. Thus compared with pure SPI film and ordinary wraps, SPI antibacterial film in the secondary freshness extended for 6 and 3 days.

From the above analysis we can see that the effect of SPI film on the freshness of pork was inferior to ordinary wraps. It may be due to the protein matrix of the SPI that provides the nutrients needed for growth. While the SPI antimicrobial film was better than the two of the antibacterial freshness for the antimicrobial agents played a key role in the inhibiting the growth of microorganisms.

\section{CONCLUSION}

SPI film has great potential to improve its antimicrobial property by incorporating antimicrobial agents. $\mathrm{N}, \mathrm{NaL}$ and EDTA at variable levels incorporating SPI film were effective in inhibiting the growth of E. Coli, Salmonella and B.cereus. $\mathrm{N}$ incorporating into SPI film increased the inhibitory zone on B.cereus to $29.58 \mathrm{~mm}$. SPI films incorporated with $\mathrm{NaL}$ had a significant antimicrobial efficacy to E.Coli and Salmonella, the inhibitory zone from $0 \mathrm{~mm}$ to 28.5 and $27.0 \mathrm{~mm}$. SPI film incorporated with EDTA showed a little antimicrobial activity against three pathogens. But it enhanced the physical properties of SPI film. The combination of $\mathrm{N}, \mathrm{NaL}$ and EDTA increased significantly the inhibitory zone against three bacteria from $0 \mathrm{~mm}$ to $32.00,33.33$, and $32.33 \mathrm{~mm}$. N, NaL and EDTA were found effective to fight against food-borne pathogens. And FTIR studies data supported the results obtained from other tests. In the application experiments, the SPI antimicrobial film (C) did have a bacteriostatic preservation effect on the meat antibacterial fresh and extend the shelf life to 3-6 days compared with pure SPI film and ordinary wraps. Overall, the incorporation of combination into SPI film had the desirable characteristic of acting as a physical and antimicrobial barrier to food contamination.

This finding has potential applications in various food products including raw and ready-to-eat product.

\section{ACKNOWLEDGEMENTS}

This study was supported by the Postdoctoral research project in Heilongjiang province (No.LBH-Q16019). The author also gratefully acknowledges the financial support from National Natural Science Fund Project. (No.31101386); 2016 Northeast Agricultural University Academic Key Project (No.16XG21); Colleges and university scientific and technological achievement industrialization of Heilongjiang (Breeding program No.1253CGZH26).

\section{AUTHORS' CONTRIBUTIONS}

Guarantor of integrity of entire study: Yuanyuan Liu, Huajiang Zhang; Study concepts: Yuanyuan Liu; Study design: Yuanyuan Liu; Literature research: Yuanyuan Liu, Lina Xu; Experimental studies: Yuanyuan Liu, Lina Xu, Yongqing Wu, Wenhui Cao, Tong Li; Data acquisition: Yuanyuan Liu, Lina Xu; Statistical analysis: Yuanyuan Liu; Manuscript preparation: Yuanyuan Liu; Manuscript definition of intellectual content: Yuanyuan Liu; Manuscript editing: Yuanyuan Liu, Lina Xu; Manuscript revision/ review: Yuanyuan Liu; Manuscript final version approval: Huajiang Zhang,Yujie Chi.

\section{REFERENCES}

Bari, M. L., D. O. Ukuku, T. Kawasaki, Y. Inatsu, K. Isshiki and S. Kawamoto. 2005. Combined efficacy of nisin and pediocin with sodium lactate, citric acid, phytic acid, and potassium sorbate and EDTA in reducing the listeria monocytogenes 
population of inoculated fresh-cut produce. J. Food Protect. 68: 1381-1387.

Branen, J. K. and P. M. Davidson. 2004. Enhancement of nisin, lysozyme, and monolaurin antimicrobial activities by ethylenediaminetetraacetic acid and lactoferrin. Int. J. Food Microbiol. 90: 63-74.

Cagri, A., Z. Ustunol and E. T. Ryser. 2001. Antimicrobial, mechanical, and moisture barrier properties of low $\mathrm{pH}$ whey protein-based edible films containing $p$-aminobenzoic or sorbic acids. J. Food Sci. 66: 865-870.

Chao, D., R. He, S. Jung and R. E. Aluko. 2013. Effect of pressure or temperature pretreatment of isolated pea protein on properties of the enzymatic hydrolysates. Food Res. Int. 54: 1528-1534.

Chen, M. 2010. Properties of Soy Protein Isolated Films and Release of Antimicrobial from Films into Fatty Food Simulants, University of Jiangnan, China.

Cheng, J. H., D. W. Sun, X. A. Zeng and H. B. Pu. 2014. Nondestructive and rapid determination of TVB-n content for freshness evaluation of grass carp (Ctenopharyngodon idella) by hyperspectral imaging. Innov. Food Sci. Emerg. Technol. 21: 179-187.

Choi, W. S. and J. H. Han. 2001. Physical and mechanical properties of pea-protein-based edible films. J. Food Sci. 66: 319-322.

Cui, S. S. 2009. Research on the properties of sustained release and bacteriostatic of antimicrobial coating containing nisin and sodium lactate, University of Jiangnan, China.

Dawson, P. L., D. E. Hirt, J. R. Rieck, J. C. Acton and A. Sotthibandhu. 2003. Nisin release from films is affected by both protein type and film-forming method. Food Res. Int. 36: 959-968.

Devlieghere, F., A. Vermeulen and J. Debevere. 2005. Chitosan: Antimicrobial activity, interactions with food components and applicability as a coating on fruit and vegetables. Food Microbiol. 21: 703-714.

Diop, C. I. K. 2011. Effects of blending, physical and chemical modifications on the properties and structure of corn(zea mays) starch based films, University of Huazhong Agriculture, China.

Duan, J. 2001. Study on the application of chitosan in preservation of chilled fresh pork. Sci. Technol. Food Ind. 22: 26-28.

Dutta, P. K., S. Tripathi, G. K. Mehrotra and J. Dutta. 2009. Perspectives for chitosan based antimicrobial films in food applications. Food Chem. 114: 1173-1182.

Eswaranandam, S., N. S. Hettiarachchy and M. G. Johnson. 2004. Antimicrobial activity of citric, lactic, malic, or tartaric acids and nisin-incorporated soy protein film against listeria monocytogenes, Escherichia coli 0157:h7, and Salmonella gaminara. J. Food Sci. 69: FMS79-FMS84.

Fukushima, D. and J. V. Buren. 1970. Mechanisms of protein insolubilization during the drying of soy milk. Role of disulfide and hydrophobic bonds. Cereal. Chem. 47: 687-695.

Gallagher, J. C., R. K. Satpathy and V. Haynatzka. 2004. The effect of soy protein isolate on bone metabolism. Menopause. 11: 290-298.

Gennadios, A., V. M. Ghorpade, C. L. Weller and M. A. Hanna. 1996. Heat curing of soy protein films. Biol. Syst. Eng. 39: 575-579.

Gennadios, A., A. H. Brandenburg, C. L. Weller and R. F. Testin. 1993. Effect of ph on properties of wheat gluten and soy protein isolate films. J. Agric. Food Chem. 41: 1835-1839.

Gontard, N., C. Duchez, J. L. Cuq and S. Guilbert. 1994. Edible composite films of wheat gluten and lipids: Water vapour permeability and other physical properties. Int. J. Food Sci. Technol. 29: 39-50.
Helander, I. M., A. V. Wright and T. M. Mattila-Sandholm. 1997 Potential of lactic acid bacteria and novel antimicrobials against gram-negative bacteria. Trends. Food Sci. Technol. 8: 146-150.

Hsu, S. T., E. J. Breukink, E. Tischenko, M. A. G. Lutters, B. De Kruijff, R. Kaptein, A. M. J. Bonvin and N. A. van Nuland. 2004. The nisin-lipid complex reveals a pyrophosphate cage that provides a blueprint for novel antibiotics. Nat. Struct. Mol. Biol. 11: 963-967.

Jin, T. and H. Zhang. 2008. Biodegradable polylactic acid polymer with nisin for use in antimicrobial food packaging. J. Food Sci. 73: $127-134$.

Juneja, V. K. 2006. Delayed clostridium perfringens growth from a spore inocula by sodium lactate in sous-vide chicken products. Food Microbiol. 23: 105-111.

Kim, K. M. 2016. Comparative study of antimicrobial effectiveness of SPI-cinnamaldehyde composite films as orocess variety of casting and coating and application. Int. J. Biosci Biotechnol. 6: 163-174.

Ko, S., M. E. Janes, N. S. Hettiarachchy and M. G. Johnson. 2001. Physical and chemical properties of edible films containing nisin and their action against listeria monocytogenes. J. Food Sci. 66: 1006-1011.

Kumar, R., V. Choudhary, S. Mishra, I. K. Varma and M. Bo. 2002. Adhesives and plastics based on soy protein products. Ind. Crops. Prod. 16: 155-172.

Kun, D. U. 2012. Synthesis of ethyl laurate catalyzed by sulfonated activated carbon under microwave irradiation. J. Anhui. Agric. Sci. 40: 1016-1019.

Li, B., J. Peng, Y. Xiao and B. Xie. 2006. Enhancing physical properties and antimicrobial activity of konjac glucomannan edible films by incorporating chitosan and nisin. J. Food Sci. 71: C174-C178.

Li, C., W. Zhu, H. Xue, Z. Chen, Y. Chen and X. Wang. 2015. Physical and structural properties of peanut protein isolate-gum Arabic films prepared by various glycation time. Food Hydrocoll. 43: 322-328.

Liu, Y. Y., X. A. Zeng and X. D. Chen. 2010. Effects of pulsed electric fields and heat treatments on SPI structure analyzed by FTIR. Spectrosc. Spectrom. Anal. 30: 2340-2344.

Long, C. and C. A. Phillips. 2003. The effect of sodium citrate, sodium lactate and nisin on the survival of arcobacter butzleri, NCTC 12481 on chicken. Food Microbiol. 20: 495-502.

Ou, S. and K. C. Kwok. 2004. Ferulic acid: Pharmaceutical functions, preparation and applications in foods. J. Sci. Food Agric. 84: 1261-1269.

Ozdemir, M. and J. D. Floros. 2005. Active food packaging technologies. CRC Crit. Rev. Food Sci. Nutr. 44: 185-193.

Park, S. K., N. S. Hettiarachchy, Z. Y. Ju and A. Gennadios, A. 2002. Formation and properties of soy protein films and coatings. In: A. Gennadios (Ed.), Protein Based Films and Coatings, CRC Press, LLC, Boca Raton, FL.

Pattanayaiying, R., A. H-Kittikun and C. N. Cutter. 2015. Incorporation of nisin $z$ and lauric arginate into pullulan films to inhibit foodborne pathogens associated with fresh and ready-to-eat muscle foods. Int. J. Food Microbiol. 207: 77-82.

Pranoto, Y., S. K. Rakshit and V. M. Salokhe. 2005. Enhancing antimicrobial activity of chitosan films by incorporating garlic oil, potassium sorbate and nisin. Lebensm Wiss Technol. 38: 859-865.

Quintavalla, S. and L. Vicini. 2002. Antimicrobial food packaging in meat industry. Meat. Sci. 62: 373-380.

Resa, C. P. O., L. N. Gerschenson and R. J. Jagus. 2016. Starch edible film supporting natamycin and nisin for improving microbiological stability of refrigerated Argentinian port salut 
cheese. Food Control. 59: 737-742.

Rhim, J. W., A. Gennadios, A. Handa, C. L. Weller and M. A. Hanna. 2000. Solubility, tensile, and color properties of modified soy protein isolate films. J. Agric. Food Chem. 48: 4937-4941.

Roy, S., A. Gennadios, C. L. Weller and R. F. Testin. 2000. Water vapor transport parameters of a cast wheat gluten film. Ind. Crops. Prod. 11: 43-50.

Sallam, K. I. 2007. Antimicrobial and antioxidant effects of sodium acetate, sodium lactate, and sodium citrate in refrigerated sliced salmon. Food Control. 18: 566-575.

Schelegueda, L. I., M. F. Gliemmo and C. A. Campos. 2012. Antimicrobial synergic effect of chitosan with sodium lactate, nisin or potassium sorbate against the bacterial flora of fish. J. Food Res. 1: 272-281.

Shiroodi, S. G., S. Nesaei, M. Ovissipour, H. M. Al-Qadiri, B. Rasco and S. Sablani. 2016. Biodegradable polymeric films incorporated with nisin: Characterization and efficiency against listeria monocytogenes. Food Bioprocess. Technol. 9: 958-969.

Silva, S. S., B. J. Goodfellow, J. Benesch, J. Rocha, J. F. Mano and R. L. Reis. 2007. Morphology and miscibility of chitosan/soy protein blended membranes. Carbohydr. Polym. 70: 25-31.

Sivarooban, T., N. S. Hettiarachchy and M. G. Johnson. 2008. Physical and antimicrobial properties of grape seed extract, nisin, and EDTA incorporated soy protein edible films. Food Res. Int. 41: 781-785.

Singh, K., R. Suri, A. K. Tiwary and V. Rana. 2012. Chitosan films: Cross-linking with EDTA modifies physicochemical and mechanical properties. J. Mater. Sci. Mater. Med. 23: 687-695.

Stevens, K. A., B. W. Sheldon, N. A. Klapes and T. R. Klaenhammer. 1991. Nisin treatment for inactivation of Salmonella species and other gram-negative bacteria. Appl. Environ. Microbiol. 57: 3613-3615.

Theinsathid, P., W. Visessanguan, Y. Kingcha and S. Keeratipibul. 2011. Antimicrobial effectiveness of biobased film against Escherichia coli 0157:h7, listeria monocytogenes and Salmonella typhimurium. Adv. J. Food Sci. Technol. 3: 294-302.

Tian, K., Z. Shao and X. Chen. 2010. Natural electroactive hydrogel from soy protein isolation. Biomacromolecules. 11: 3638-3643.

Tian, K., J. Guan, Z. Shoo and C. Xin. 2008. Structural and functional study of soybean protein isolation. Prog. Chem. 20: 565-573.

Ukuku, D. O. and W. F. Fett. 2004. Effect of nisin in combination with EDTA, sodium lactate, and potassium sorbate for reducing Salmonella on whole and fresh-cut cantaloupet. J. Food Protect.
67: 2143-2150.

Vaara, M. 1999. Lipopolysaccharide and the permeability of the bacterial outer membrane. In: H. Brade, S. M. Opal, S. N. Vogel and D. C. Morrison (Eds.), Endotoxin in Health and Disease, Marcel Dekker, Inc., New York, Basel, pp. 31-38.

Walsh, S. E., J. Y. Maillard and A. D. Russell. 2003. Activity and mechanisms of action of selected biocidal agents on grampositive and -negative bacteria. J. Appl. Microbiol. 94: 240-247.

Wan, V., M. S. Kim and S. Y. Lee. 2005. Water vapour permeability and mechanical properties of soy protein isolate edible films composed of different plasticizer combinations. J. Food Sci. 70: e387-e391.

Wang, H., D. Hu, Q. Ma and L. Wang. 2016. Physical and antioxidant properties of flexible soy protein isolate films by incorporating chestnut (Castanea mollissima) bur extracts. LWT Food Sci. Technol. 71: 33-39.

Wang, H., R. Zhang, H. Zhang, S. Jiang, H. Liu, M. Sun and S. Jiang. 2015. Kinetics and functional effectiveness of nisin loaded antimicrobial packaging film based on chitosan/poly(vinyl alcohol). Carbohydr. Polym. 127: 64-71.

Wang, H., R. Zhang, J. Cheng, H. Liu, L. Zhai and S. Jiang. 2015. Functional effectiveness and diffusion behavior of sodium lactate loaded chitosan/poly(I-lactic acid) film with antimicrobial activity. RSC. Adv. 5: 98946-98954.

Were, L., N. S. Hettiarachchy and M. Coleman. 1999. Properties of cysteine-added soy protein-wheat gluten films. J. Food Sci. 64: 514-518.

Yang, W. G., M. H. Ma and F. K. Zhang. 2002. Application of three antimicrobial agents in meat products. Meat. Ind. 8: 20-27.

Yildirim, M. and N. S. Hettiarachchy. 1997. Biopolymers produced by cross-linking soybean $11 \mathrm{~s}$ globulin with whey proteins using transglutaminase. J. Food Sci. 62: 270-275.

Yong, J. K., B. J. Ahn, H. W. Choi, H. S. Kim and Y. H. Lee. 2007. Preparation and characterization of chitosan/cellulose acetate blend film. J. Korea. Soc. Dyers Finishers. 19: 10-17.

Yun, X. X., J. Hu and Q. Chen. 2006. Observation on inhibitory effect of nisin on enter ptoxin Escherichia coli. Chin. J. Disinfect. 23: 529-531.

Zhao, S., J. Yao, X. Fei, Z. Shao and X. Chen. 2013. An antimicrobial film by embedding in situ, synthesized silver nanoparticles in soy protein isolate. Mater. Lett. 95: 142-144.

Zhao, D. 2013. Study on Antifungal Membrane of Edible Starch, University of Jilin Agriculture, China. 